\title{
Evaluation of Available Building Integrated Photovoltaic (BIPV) Systems and their Impact when Used in Commercial Buildings in the United Arab Emirates
}

\author{
Maria Gabriela Soto Conde, Kirk Shanks \\ Heriot Watt University
}

\begin{abstract}
The utilization of building integrated photovoltaic (BIPV) systems represents an opportunity to turn building envelopes to elements that harness solar energy. The performance of BIPV elements is linked to external conditions such as location, inclination and thermal conditions. Cell temperature is a critical factor that affects not only the electrical performance of photovoltaics but when applied onto a building, can also affect its internal ambient temperature and comfort. These effects need to be addressed, particularly in hot climates. This paper discusses the impact of the implementation of BIPV systems on the cooling load of a typical commercial building located in the United Arab Emirates, where cooling systems tend to be utilized constantly throughout the year. It also analyzes the potential of BIPV systems to perform as per their technical specifications as set at standard test conditions (STC) by studying the thermal behavior of BIPV systems as applied in local thermal conditions. The BIPV systems analyzed under UAE conditions resulted in an increase on the building's cooling load and a decrease in the systems' electrical output, suggesting the need of implementing techniques to control the systems' temperature or the modification of systems to be more adequate for utilization in the region.
\end{abstract}

\section{Introduction}

Energy consumption is growing in spite of the efforts to produce and utilize energy efficient systems. Globally, buildings represent $40 \%$ of primary energy usage and if the energy consumed in manufacturing steel, cement, aluminum and glass used in construction is included, the number grows to more than $50 \%$ [1]. Within this classification, the main consumers of energy are residential and commercial buildings, constituting $32.6 \%$ of the world's energy consumption [2]. In the United Arab Emirates and specifically in the emirate of Dubai, commercial buildings account for $48 \%$ of the total electricity consumption [3] and up to $80 \%$ of a typical building's total electricity demand is for cooling [4] [5].
Building integrated renewables, specifically photovoltaics, are technologies that are used to replace conventional building materials while also generating electricity for the building. They provide on-site renewable energy, eliminating transmission costs and contributing to the building's rating according to systems such as LEED, BREEAM or Estidama, which incentivize the use of renewables on site [6]. BIPV systems have been implemented in different countries in Europe, America and Asia, but they haven't yet been widely applied in the Middle East. The first reason that comes to mind is that they are not economically sensitive, and a simple study can demonstrate that return of investment periods are very long.

However, in the past decades, the cost of renewables has decreased significantly. The ultimate goal for technology developers is to make BIPV cost competitive with the building materials it replaces [6], so it can be presumed that this decrease will continue and that BIPV systems will be available at lower rates, making then more financial sense to implement them. It is important to monitor prices, understand what is driving the use of renewables, and being able to recognize when and where to utilize BIPV systems.

Other than the comparison in between the cost of the PV systems and the cost of the building materials, a crucial factor is the efficiency of energy production of these systems. At the moment, in the Middle East and due to the region's significant subsidies on energy derived from non-renewable sources and the current energy conversion efficiency of PV, payback time for the systems exceeds the lifetime of the installation, hence not being financially sensible to install. The subsidies for national supplied electricity are likely to be reduced in the near future [7], which will make the implementation of BIPV technologies more financially viable.

It can be assumed that technology will develop rapidly, increasing the panels' efficiency and eventually being on the pair with the cost of electricity. However, when only 5 to $20 \%$ of the solar radiation on a panel is converted into electricity [9] , the remainder still contributes to the increase of the PV module temperature. At standard test conditions, this increase in temperature causes a reduction of the 
efficiency of the module, and this percentage decrease is identified as "temperature coefficient". The values range around $-0.25 \%$ per degree Celsius above the standard test conditions (STC) and nominal operating cell temperatures (NOCT) used by laboratories and product manufacturers when testing their systems. The consideration of the differences between STC conditions and the ambient characteristics of the UAE is critical. STC and NOCT test conditions can be found on Table 1.

Table 1. STC and NOCT test conditions [10]

\begin{tabular}{|c|c|c|c|}
\hline \multicolumn{5}{|c|}{ STC and NOCT test conditions } \\
\hline & $\begin{array}{c}\text { Irradiance } \\
(\mathrm{W} / \mathrm{m} 2)\end{array}$ & $\begin{array}{c}\text { Temperature } \\
\text { of PV cell } \\
\left({ }^{\circ} \mathrm{C}\right)\end{array}$ & $\begin{array}{c}\text { Ambient air } \\
\text { temperature } \\
\left({ }^{\circ} \mathrm{C}\right)\end{array}$ \\
\hline STC & 1000 & 25 & - \\
NOTC & 800 & - & 20 \\
\hline
\end{tabular}

It is estimated that variance will be found when comparing the BIPV systems performances with standard test conditions versus real UAE conditions, with efficiency dropping by up to 4 percentage points [11].

When applied onto a building, the increase in temperature does not only affect the energy conversion rate, but can possibly be transferred into the building that they are covering. If this is the case, this heat exchange could be detrimental to the total energy consumption of a building located in a year-round warm climate like the UAE, since more energy would be consumed by air conditioning systems to keep the comfort standards for the occupants inside.

Façade materials such as glass can incorporate insulation technologies to decrease the heat gain in buildings, and local regulations call for façade materials to comply with low $U$ values, promoting energy efficiency. When façade elements are replaced by BIPV and if the PV element's temperature rises, it would be expected that the heat gain inside would be higher. On the other hand, if the utilization of BIPV contributed to the building's insulation by having better thermal properties than the ones of the material that it is substituting, then a further saving should be added considering that not only the system is producing electric energy but also reducing the amount of energy used by air conditioning systems (cooling and heating load) in the establishment.

The main gap found during the literature review is the incorporation of BIPV and its effects on the inside of buildings as applied specifically in the Middle East's weather conditions. In terms of energy savings potential in other parts of the world, BIPV units outperform other commonly used glazing systems when integrated in highly glazed buildings, as per studies done in areas where the temperature variations throughout a year require interior heating during the winter and cooling during the summer [12]. This report has been prepared after modelling different BIPV systems on a commercial building located in the UAE in order to draw applicable conclusions.

It is important to analyze the effects of location into an energy model. The consideration of localized climate and insolation is essential for the evaluation of any type of PV, and conclusions should not be taken lightly by assuming that results are valid for any location. The UAE has extreme conditions of heat and humidity, and a particular behavioral pattern of occupants of using air conditioning system year round. Studies have determined that energy payback periods for PV systems are shorter in areas with higher insolation, since energy production is higher, while others have stated that external electricity consumption in buildings could be reduced by up to $55 \%$ using optimum BIPV systems [14].

The purpose of this dissertation is to evaluate and compare the utilization of BIPV in a typical office building in the United Arab Emirates. The vast majority of office buildings in the area are multilevel, ranging from 10 to 30 floors, and with a square footprint, due to space flexibility and construction common practice. Tower blocks are considered to be the most vulnerable building type to climate variations and in particular solar impact, since they have large surfaces exposed to the elements and often an unfavorable volume to surface ratio [15].

Section 1 of this report demonstrates the project's methodology and the effects of the installation of different BIPV elements onto the cooling load of an office building, while section 2 compares the expected results in terms of energy production and efficiency of the systems at standard test conditions against a more accurate representation of the thermal conditions in the UAE. Section 3 is a simple analysis of the cost of BIPV and their payback periods. Finally, the main findings of the study are discussed, and conclusions are drawn.

\section{Methodology}

\subsection{Approach}

In order to model BIPV systems applied in an office building in the UAE, it was necessary to find a reliable source of information that could constitute the baseline for the weather and temperature parameters in the area. It was determined that the parameters needed were solar incidence on a given surface, surface temperature changes and cooling load measurements for a building. The software IES VE is an internationally utilized software for energy modeling 
that can provide, amongst many other variables, the ones needed for this simulation. Within the software, it is also possible to specify the exact location of the building. The program then utilizes the region's physical characteristics that are already in its database.

A typical office building was modelled using the applications Model IT, to model the building; SunCast to model the solar path at the specified location; and ApacheSimcalc to model solar gain, incident solar power, internal temperatures and cooling plant loads in an average year. The building is comprised by a ground floor plus 7 stories, and its façade incorporates aluminum composite panels as cladding on solid walls and double glazed windows. The glazing area is 58\% of the façade, which is common in current regional architecture. The location chosen was Dubai and in the orientation of its main road, since many roads and buildings follow this configuration.

In recent years and in an effort to pursue sustainable development, local authorities have introduced the Green Building Regulations and Specifications to be adopted on all buildings in Dubai. The building's envelope was modeled to comply with the mandatory minimum performance requirements as per these regulations. Table 2 shows the requirements in terms of thermal performance [16].

Table 2. Minimum Performance Requirements for External Walls and Glazing

Building elements forming the external walls, roofs, and floors (where one side of the floor is exposed to ambient conditions) must have an average thermal transmittance (U value) which does not exceed the following values:

\begin{tabular}{|c|c|}
\hline Roof & $\mathrm{U}=0.3 \mathrm{~W} / \mathrm{m}^{2} \mathrm{~K}$ \\
\hline External Wall & $\mathrm{U}=0.57 \mathrm{~W} / \mathrm{m}^{2} \mathrm{~K}$ \\
\hline \multicolumn{2}{|c|}{$\begin{array}{l}\text { Glazed Elements: Fenestration } \\
\text { If the total area of external walls that let in light is } \\
\text { between forty percent }(40 \%) \text { and sixty percent }(60 \%) \text { of } \\
\text { the external wall area, then the glazing elements must } \\
\text { meet the following performance criteria: }\end{array}$} \\
\hline $\begin{array}{l}\text { Thermal Transmittance } \\
\text { (Summer U Value) }\end{array}$ & $\mathrm{U}=1.9 \mathrm{~W} / \mathrm{m}^{2} \mathrm{~K}$ \\
\hline Shading Coefficient (SC) & $0.32(\max )$ \\
\hline Light Transmittance & $0.1(\min )$ \\
\hline
\end{tabular}

\subsection{Base case}

To simulate a typical office building, each of the floors in the model was composed by offices on the perimeter of the building, a main hall, toilets and lift shafts. In order to minimize the variables that could influence the results of the model, it was assumed that all floors would be identical, and no lobbies, parking, retail or service areas were included. A typical office floor plan, indicating the location of external walls and windows, is shown in Figure 1.

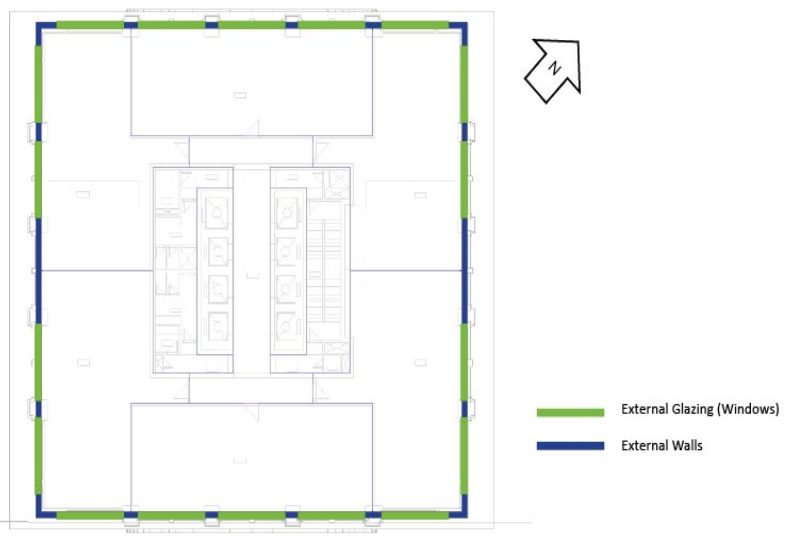

Figure 1. Typical office floor plan

For the base case, the external walls of the model are composed of composite aluminum panels as cladding on the outside with a thickness of $4 \mathrm{~mm}$, a $100 \mathrm{~mm}$ void, lightweight concrete block with a thickness of $260 \mathrm{~mm}$ and $4 \mathrm{~mm}$ plaster layer. The uvalue for the wall element results in $0.56 \mathrm{~W} / \mathrm{m}^{2} \mathrm{~K}$, which meets the requirements of the Dubai Green Building Regulations.

The windows are composed by a double-glazed glass, with two $6 \mathrm{~mm}$ panes and an argon gap of 12 $\mathrm{mm}$ in between. The net $\mathrm{u}$-value for this element is $1.68 \mathrm{~W} / \mathrm{m}^{2} \mathrm{~K}$ and the solar heat gain coefficient (SHGC) is 0.15 , which exceeds the requirements of the Dubai Green Building Regulations. The specifications of the glass chosen can be found in the appendix.

The fourth floor of the building was chosen as a test location in order to simplify the model and to select an area that would constitute a representation of the building. This was due to its location in the middle of the structure, which is less likely to be influenced by location specific factors such as heat gain from the roof, basements or plant rooms. The maximum solar gain and cooling load was identified on a room labeled "4 Office 5", located in the southeastern façade of the fourth floor and identified in Figure 2. These floor and office were selected as the locations for which the energy evaluation would be made. The cooling system was set continuously on at 23 degrees Celsius. 


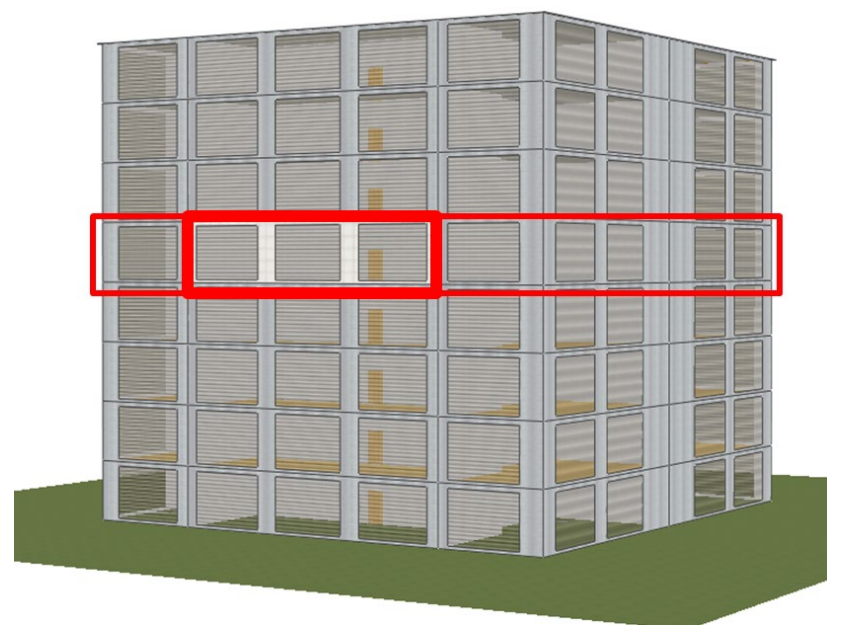

Figure 2. Test Location

\subsection{Modeling of BIPV Systems}

Three BIPV systems were chosen based on their applicability and their availability in the market. These are panels that have not been used in the UAE but have been installed in other parts of the world, and that are being promoted in the region for implementation in local projects. In order to represent the two façade elements that could be substituted by BIPV, both glass and wall BIPV systems were chosen, testing one glass system and two wall systems. The two wall systems were selected as a function of their aesthetic appearance, as one can be easily identified as a solar element while the other can be concealed within a regular façade due to its color and pattern.

The three different panels, their physical and technical characteristics are shown in Table 3 while Table 4 summarizes the four models that were created to compare the systems.

Table 3. Characteristics of the Analyzed BIPV Systems

\begin{tabular}{|l|l|l|l|} 
BIPV System & BIPV 1 & BIPV 2 & BIPV 3 \\
\cline { 1 - 2 } Commercial Name & Calyxo & Onyxsolar Glass & Kromatix \\
\hline Installation element & Façade Wall & $\begin{array}{l}\text { Fache Window (External } \\
\text { Glazing) }\end{array}$ & Façade Wall \\
\hline Measurements of one panel & $1200 \times 600 \mathrm{~mm}$ & $1245 \times 2456 \mathrm{~mm}$ & $1640 \times 1000 \mathrm{~mm}$ \\
\hline Area of one panel & 0.72 & 3.05772 & 1.64 \\
\hline Cell Type & $\begin{array}{l}\text { Cadmium } \\
\text { Telluride/Cadmium } \\
\text { Sulfide (CdTe) }\end{array}$ & Amorphous silicon (a-Si) & $\begin{array}{l}\text { Mono-crystalline Silicon } \\
\text { (mono-Si) }\end{array}$ \\
\hline Peak Power $(\mathbf{W})$ & 75 & 145.6 & 240 \\
\hline Peak Power per sqm $\mathbf{( W / m 2 )}$ & 104.2 & 47.6 & 146.3 \\
\hline Stated Efficiency at STC (\%) & $10.42 \%$ & $4.76 \%$ & $14.63 \%$ \\
\hline
\end{tabular}

Technical and physical characteristics of the panels such as efficiency, aesthetics, size and cost were taken either from the product datasheets or directly from the product manufacturers. However, for a correct evaluation and comparison, the parameters heat gain and surface temperature change over time were taken as results from the IES model.

The end results were expected to provide data to perform an evaluation of the available systems, their efficiency, and their contributions to a building's energy performance.

\section{Results}

\subsection{Section 1 - Analysis of the effect of BIPV systems on a commercial building's cooling load}

After running a first set of models, it was found that there was a significant difference in the cooling load when implementing BIPV 2, which was applied on glass, to when implementing BIPV systems on walls.

For a correct comparison between the glazing systems, the elements chosen had a close Solar Heat 
Table 4. Summary of Models

\begin{tabular}{|c|c|c|c|c|}
\hline & Model & External Wall Description & $\begin{array}{l}\text { External Glazing (Window) } \\
\text { Description }\end{array}$ & Appearance \\
\hline 1 & $\begin{array}{l}\text { No PV } \\
\text { Panels }\end{array}$ & $\begin{array}{l}\text { Compliant with Dubai } \\
\text { Municipality regulations. } \\
\text { Aluminium composite panel } \\
\text { cladding, lightweight masonry } \\
\text { blocks and plaster } \\
\text { U value }=0.56\end{array}$ & $\begin{array}{l}\text { Compliant with Dubai } \\
\text { Municipality regulations. } \\
\text { Double glazing with argon gap. } \\
\text { U value }=1.68 \\
\text { SHGC }=0.15\end{array}$ & \\
\hline 2 & $\begin{array}{l}\text { BIPV } 1 \\
\text { Wall }\end{array}$ & $\begin{array}{l}\text { Calyxo façade substitutes the } \\
\text { Aluminium composite panel } \\
\text { cladding. } \\
\text { U value }=0.53\end{array}$ & $\begin{array}{l}\text { Compliant with Dubai } \\
\text { Municipality regulations. } \\
\text { Double glazing with argon gap } \\
\text { U value }=1.68 \\
\text { SHGC }=0.15\end{array}$ & \\
\hline 3 & $\begin{array}{l}\text { BIPV } 2 \\
\text { Window }\end{array}$ & $\begin{array}{l}\text { Compliant with Dubai } \\
\text { Municipality regulations. } \\
\text { Aluminium composite panel } \\
\text { cladding, lightweight masonry } \\
\text { blocks and plaster } \\
\text { U value }=0.56\end{array}$ & $\begin{array}{l}\text { Onyx solar glass substitutes the } \\
\text { external glazing. } \\
\text { U value }=2.93 \\
\text { SHGC }=0.20\end{array}$ & \\
\hline 4 & $\begin{array}{l}\text { BIPV } 3 \\
\text { Wall }\end{array}$ & $\begin{array}{l}\text { Kromatix façade substitutes the } \\
\text { Aluminium composite panel } \\
\text { cladding. } \\
\text { U value }=0.57\end{array}$ & $\begin{array}{l}\text { Compliant with Dubai } \\
\text { Municipality regulations. } \\
\text { Double glazing with argon gap } \\
\text { U value }=1.68 \\
\text { SHGC }=0.15\end{array}$ & \\
\hline
\end{tabular}

Gain Coefficient (SHGC), which is the percent of solar energy incident on the glass that is transferred indoors both directly and indirectly through the glass. In locations with a long air-conditioning season, like the UAE, SHGC is a critical factor that influences solar gain and therefore air-conditioning loads. The SHGC for the BIPV glass was 33\% higher than that of the glass with no BIPV, therefore this contributed to the $42 \%$ increase in cooling loads that was found. Other factor that contributed to this increase is the $75 \%$ difference in U-values from the non-BIPV glass to the BIPV glass element $(1.68$ and 2.93, respectively). It is also important to note that the larger part of the whole façade is glass $(58 \%)$, so a change in this parameter means a large impact on the overall result.

The monthly totals for cooling loads on the test location are shown in Figure 3.

It was also identified that there was only a negligible difference in cooling load when utilizing wall BIPV systems, when compared to a model that did not use BIPV panels at all but complied with local municipality regulations.

The insulation properties of the lightweight concrete blocks located behind the wall BIPV could have contributed to the negligible increase in cooling loads, however BIPV elements can reach temperatures on the inclined plane and vertical plane of $67.2^{\circ} \mathrm{C}$ and 


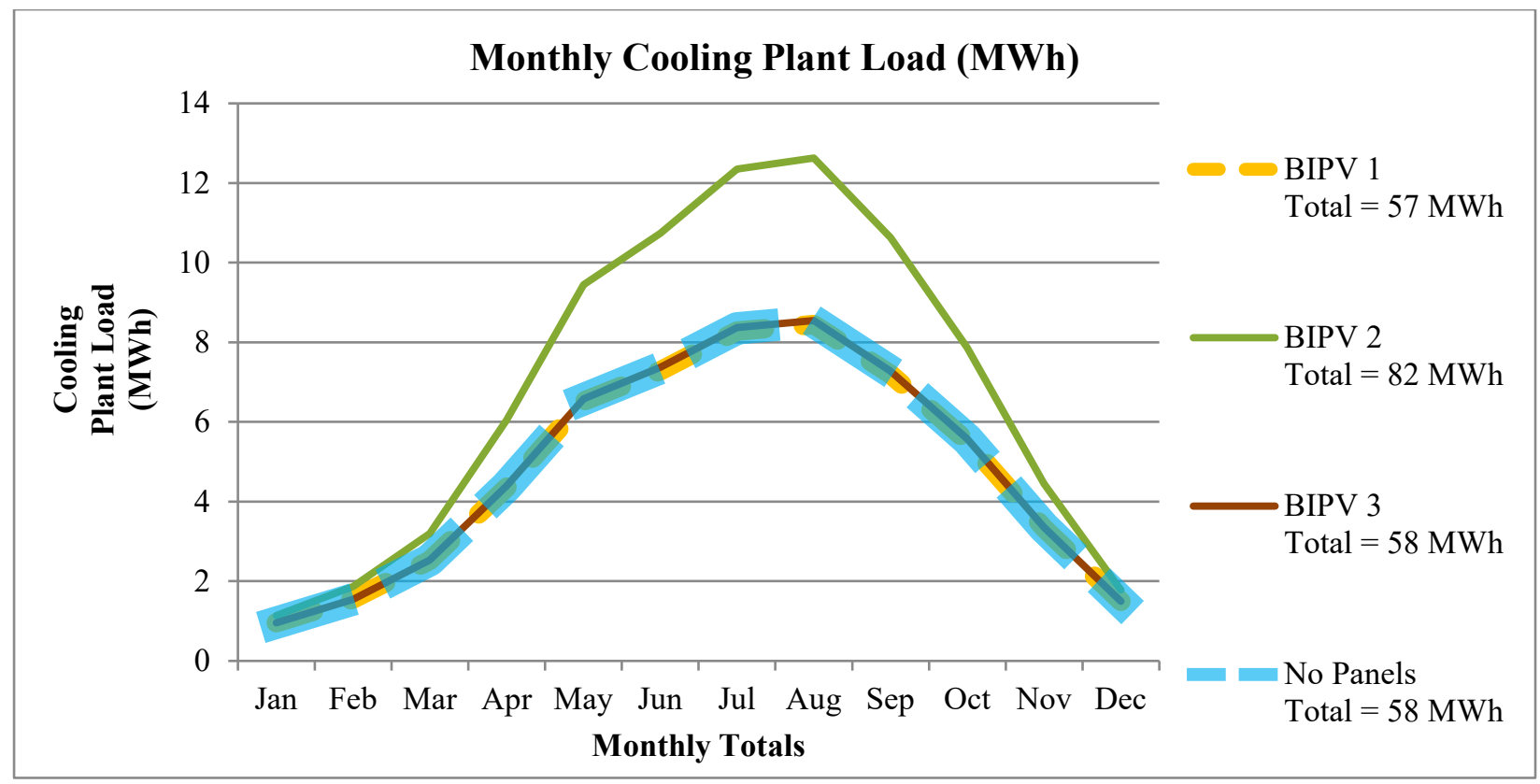

Figure 3 - First evaluation of BIPV Systems Results for cooling plant load for the 4th floor office (MWh) monthly totals with cooling on continuously

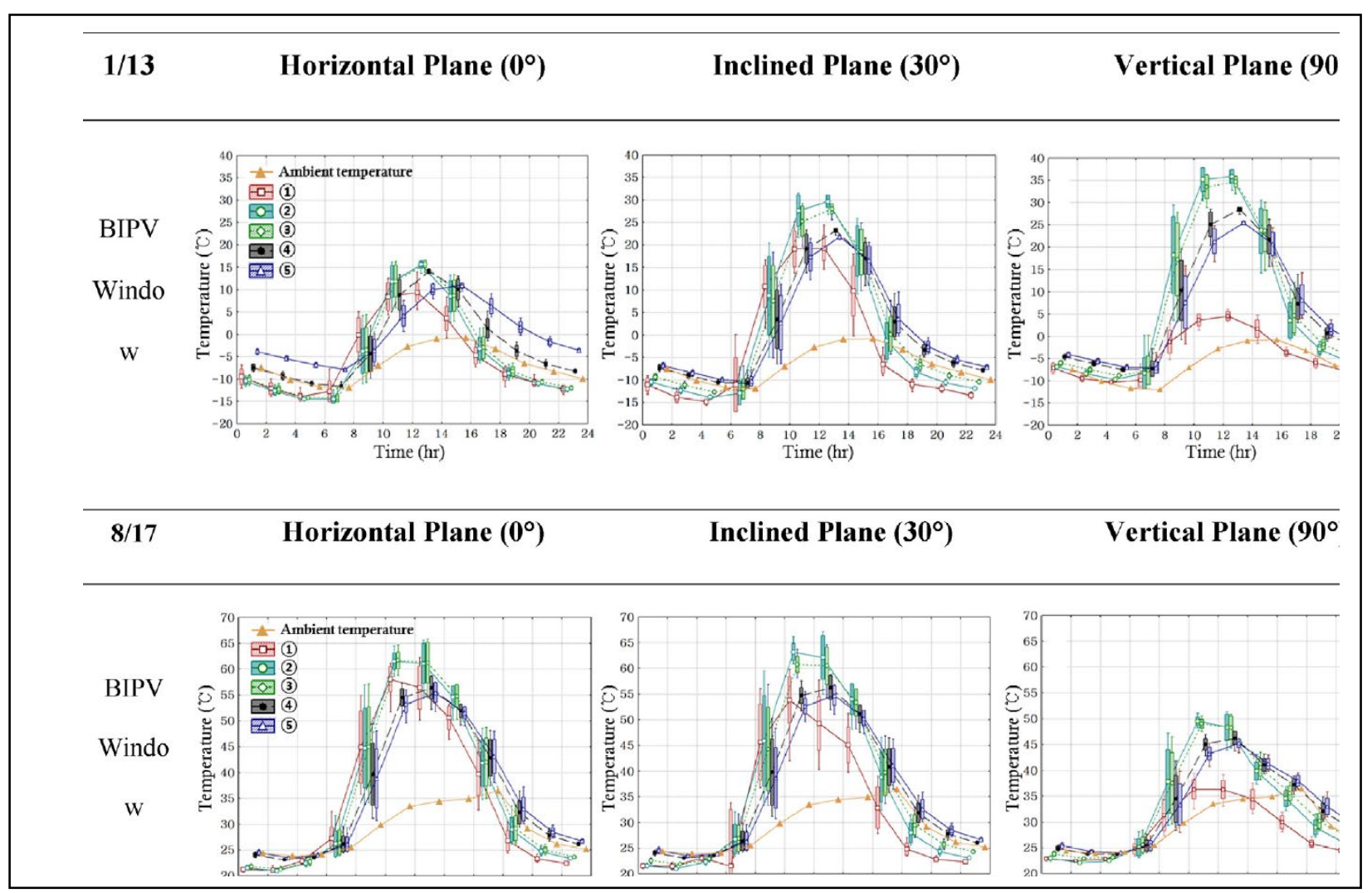

Figure 4 - Hourly temperature variations for BIPV systems on the typical day of winter season (January 13) and summer season (August 17) in South Korea 
$51.9{ }^{\circ} \mathrm{C}$ respectively, as measured in other geographical locations [17]. These temperatures have been found in areas where the geographical conditions are apt for high temperatures during the summer months and low temperatures during the winter months. Figure 6 shows the work of Yoon et al, reporting the temperatures recorded in BIPV elements and their comparison to the ambient temperature during a typical winter and summer day in South Korea.

The results reported by Yoon et al, illustrated in Figure 4, show that during the winter, when ambient temperatures fluctuate from -12 to 0 degrees, BIPV elements reach temperatures between 15 and 35 degrees during the day. On the other hand, during the summer, ambient temperatures were recorded between 27 and 37 degrees while the BIPV panels stayed between 37 and 52 .

Based on these results and making a conservative and cautious estimate, it was assumed that if the average air temperature during the winter in the UAE is $27{ }^{\circ} \mathrm{C}$ [18], the BIPV elements would heat up to 40 degrees, while during the summer the air temperature reaches an average high of 39 degrees so the BIPV elements would be modeled at an average of 55 degrees. These values were modeled by the modification of outside temperatures in the areas adjacent to the location of BIPV elements on walls. The temperature of PV modules rises and drops slowly, indicating that there is a time lag effect between the PV module temperature and the solar radiation [19]. The outside temperatures were set daily from 9:30 am to $4: 30 \mathrm{pm}$ at a constant $55^{\circ} \mathrm{C}$ during the months of May through October and $40^{\circ} \mathrm{C}$ from November through April. The results found are shown in Table 5 and Figure 5.

This was done only for BIPV 1 and 3, which are wall elements, and considering they have similar thermal properties. BIPV 2 was not modeled since the initial results showed that its utilization meant a great increase in cooling load for the building even without considering its temperature raise.

It was then found that the annual cooling load increased by $22 \%$ due to the temperature increase of the installed wall BIPV elements. As expected, the increase was more significant during the summer months, when the cooling loads are typically higher and the BIPV elements would reach higher temperatures.

An additional model was created by incorporating mineral wool as an insulation layer in between the modeled hot panels and the façade of the building, substituting the $100 \mathrm{~mm}$ wide void modeled in the base case, introducing a better thermal resistance for the façade. As expected, the cooling load for the office floor was lower with the implementation of insulation, representing a $5 \%$ reduction in cooling load from the model with no insulation and an $18 \%$ increase from the model with no panels. The results after the inclusion of the mineral wool insulation layer are shown in Figure 6.

It was found that all three types of BIPV systems increase the cooling load of the building they were applied onto, and this is mainly due to the difference in thermal properties of the BIPV elements in contrast to those of the façade elements that they replace. For the BIPV glass, the difference in U-values from normal glass caused a significant raise of the yearly cooling load, while for the BIPV wall elements, it was the additional heat generated within their PV component. The results for all the models can be seen on Figure 7.

\subsection{Section 2 - Representation of the model against standard test conditions}

\section{Cell Efficiency}

An analysis was made to estimate if BIPV systems could perform as per their specifications in the thermal conditions of the UAE. At standard test conditions, the cell temperature is 25 degrees, but as it has been shown in section 1, this is not the usual temperature of installed BIPV panels.

To model the surface temperature conditions of the building, the external surface incident solar radiation for a localized area, measured in kilowatts, was taken from the model, for the whole year, every hour. For each of these values, a corresponding external surface temperature was estimated. Two sets of tests were done to analyze the influence of temperature change in the BIPV elements:

A) Outside surface temperature based on the outside air temperature and through a set of models considering only the outside layer of the envelope. One of the software's limitations is that it is not possible to measure the outside surface temperature of elements, but only the inside. For this reason, each of the BIPV models on Table 2 was modified to remove all internal elements of the façade (lightweight concrete block and plaster for the walls and the argon gap and inside glass pane for glazing). This way, it was possible to know the surface temperature at the outer layer of the BIPV system, where the PV element would be located. 
Table 4. Cooling load for the 4th floor when modeling BIPV elements at high temperatures

\begin{tabular}{|c|c|c|}
\hline Month & $\begin{array}{l}\text { Cooling load for the } 4^{\text {th }} \text { floor as modeled } \\
\text { with no BIPV elements } \\
\text { Total }=58 \mathrm{MWh}\end{array}$ & $\begin{array}{l}\text { Cooling load for the } 4^{\text {th }} \text { floor as modeled with } \\
\text { wall BIPV elements set at } 40 \text { and } 55^{\circ} \mathrm{C} \text { (winter } \\
\text { and Summer) } \\
\text { Total }=71 \mathrm{MWh}\end{array}$ \\
\hline Jan & 0.96 & 0.92 \\
\hline Feb & 1.55 & 1.59 \\
\hline Mar & 2.53 & 2.81 \\
\hline Apr & 4.38 & 4.90 \\
\hline May & 6.57 & 8.51 \\
\hline Jun & 7.35 & 9.45 \\
\hline Jul & 8.35 & 10.63 \\
\hline Aug & 8.52 & 10.73 \\
\hline Sep & 7.26 & 9.13 \\
\hline Oct & 5.56 & 7.04 \\
\hline Nov & 3.35 & 3.50 \\
\hline Dec & 1.50 & 1.58 \\
\hline Summed total & $\mathbf{5 7 . 8 9}$ & 70.78 \\
\hline
\end{tabular}

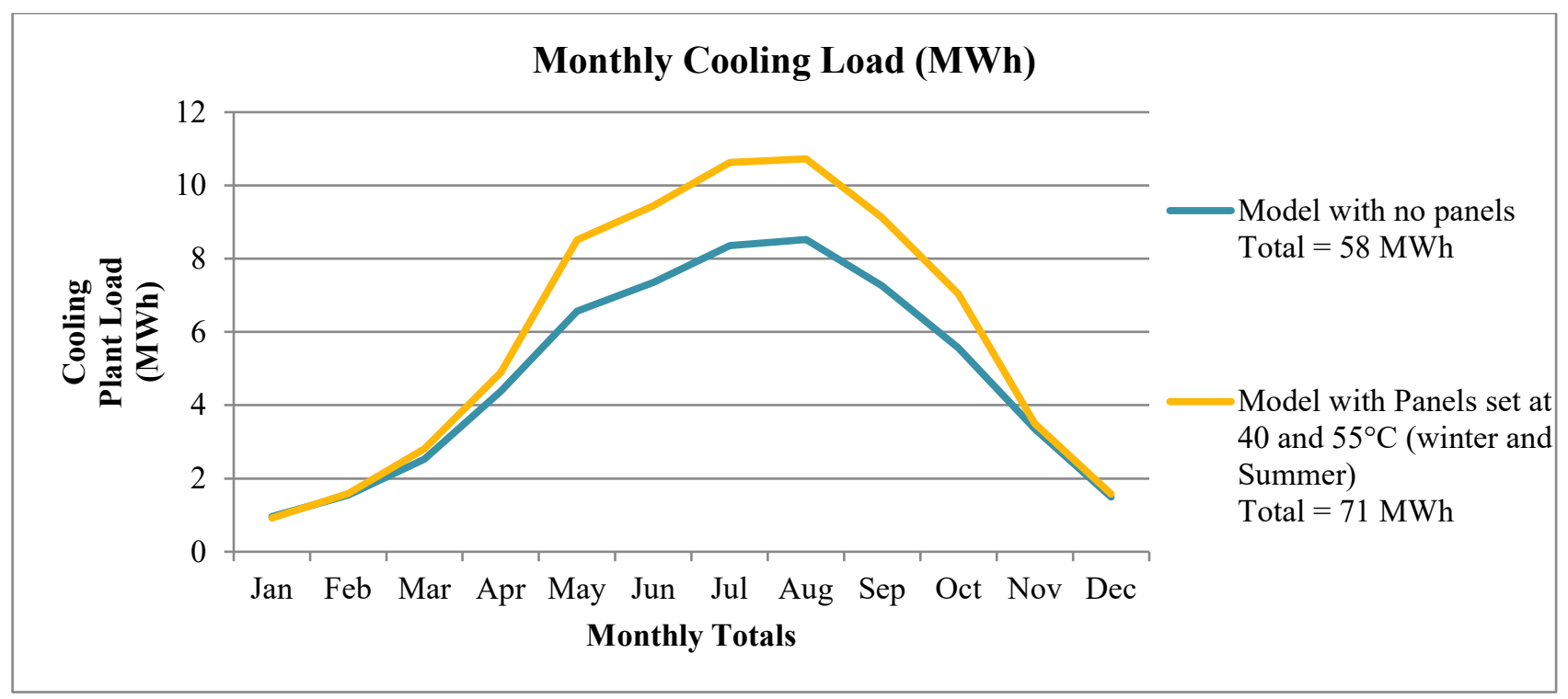

Figure 3. Graphical representation of the cooling plant load for the 4th Floor when modeling outside surface temperatures of BIPV elements 


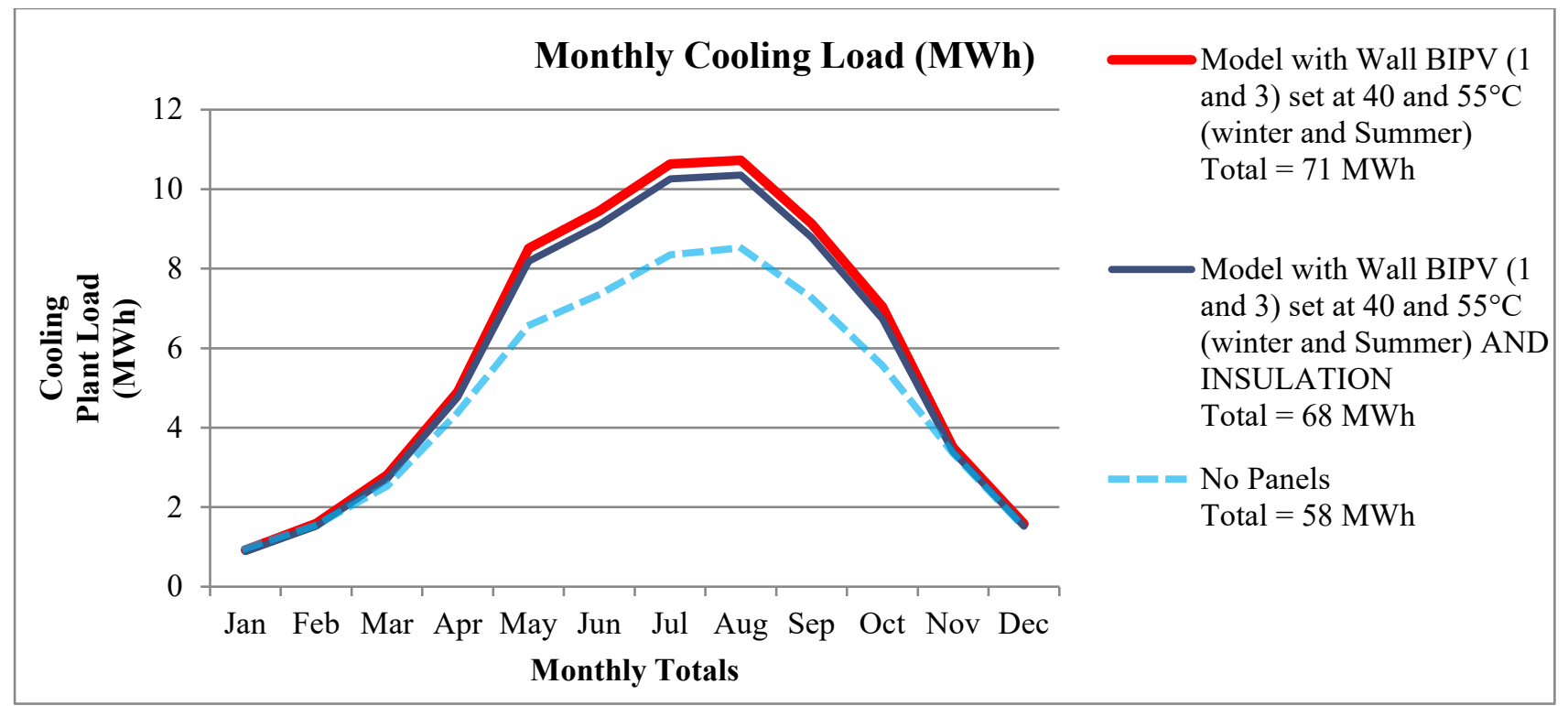

Figure 4. Cooling plant load when setting the outside temperature of BIPV at high temperatures and when incorporating an insulation element

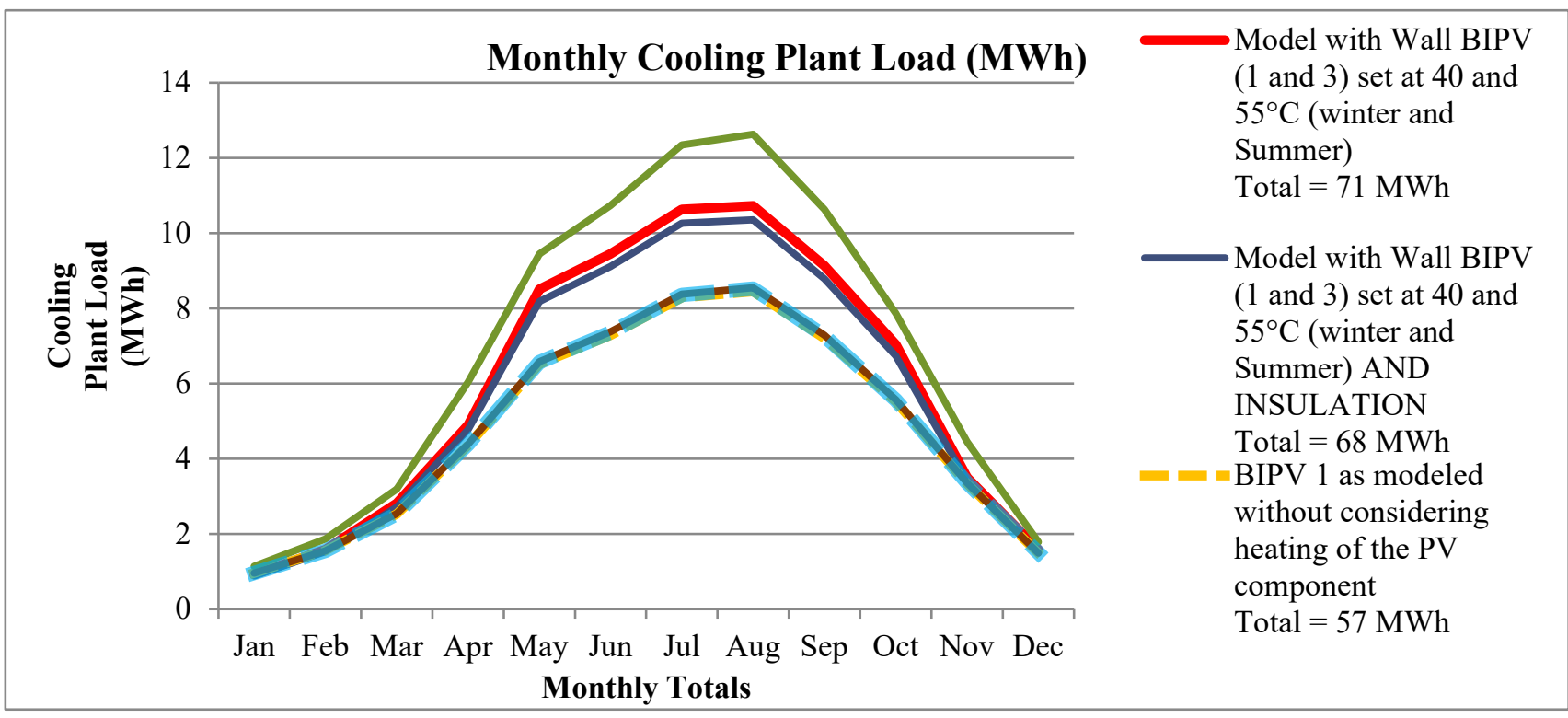

Figure 5. Cooling Plant Load for the 4th Floor. Representation of all the models simulated

B) Outside surface temperatures modeled at $40^{\circ} \mathrm{C}$ during the winter and $55^{\circ} \mathrm{C}$ during the summer, as was done when estimating the building cooling load and as per section 1 of this report.

Using each BIPV system's temperature coefficient, as reported by manufacturers, and multiplying it by the difference between the panel temperature and the standard test conditions, a reduced efficiency was calculated for both cases A and B.

The summary of results from this calculation and the efficiencies under non-standard test conditions is shown in Table 6. 
Table 5. Summary of Efficiencies as modeled on non-Standard test condition

\begin{tabular}{|c|c|c|c|c|}
\hline Efficiency calculations for 4 th floor & & BIPV 1 & BIPV 2 & BIPV 3 \\
\hline Commercial Name & & Calyxo & $\begin{array}{l}\text { Onyxsolar } \\
\text { Glass } 3+3,10 \%\end{array}$ & $\begin{array}{l}\text { Kromatix, } \\
\text { Gray }\end{array}$ \\
\hline $\begin{array}{l}\text { Available area of BIPV system for the whole } \\
\text { floor }\end{array}$ & sqm & 229.00 & 315.00 & 229.00 \\
\hline $\begin{array}{l}\text { Incident Solar Radiation on the element } \\
\text { modeled (one window or wall, data from } \\
\text { model) }\end{array}$ & $\mathrm{kWh}$ & $29,392.06$ & $20,824.33$ & $29,392.06$ \\
\hline Size of the element modeled & sqm & 24.70 & 17.50 & 24.70 \\
\hline $\begin{array}{l}\text { Incident Solar Radiation per sqm on the } \\
\text { element modeled }\end{array}$ & $\mathrm{kWh} / \mathrm{sqm}$ & $1,189.96$ & $1,189.96$ & $1,189.96$ \\
\hline Efficiency at STC & & $10.42 \%$ & $4.76 \%$ & $14.63 \%$ \\
\hline $\begin{array}{l}\text { Efficiency from model assuming outside } \\
\text { temperature conditions and through a model } \\
\text { of the outside layer of the envelope }\end{array}$ & & $9.96 \%$ & $4.63 \%$ & $13.69 \%$ \\
\hline $\begin{array}{l}\text { Efficiency assuming panels reach } 40 \text { and } 55 \\
\text { degrees during winter and summer, } \\
\text { respectively }\end{array}$ & & $9.91 \%$ & $4.59 \%$ & $13.59 \%$ \\
\hline Energy produced at STC & $\mathrm{kWh}$ & $28,385.55$ & $17,848.73$ & $39,878.24$ \\
\hline $\begin{array}{l}\text { Energy produced assuming outside } \\
\text { temperature conditions and a model of the } \\
\text { outside layer of the envelope }\end{array}$ & $\mathrm{kWh}$ & $27,152.40$ & $17,352.58$ & $37,314.25$ \\
\hline $\begin{array}{l}\text { Energy produced assuming panels reach } 40 \text { - } \\
\text { and 55-degrees during winter and summer, } \\
\text { respectively }\end{array}$ & $\mathrm{kWh}$ & $27,017.61$ & $17,211.26$ & $37,033.98$ \\
\hline
\end{tabular}

The decreases in the systems' efficiencies range from 0.5 to 1.04 percentage points, but these slight decreases translate into 4 to $7 \%$ decrease in the energy production of the installed BIPV systems.

When comparing the outside surface temperatures in between models $\mathrm{A}$ and $\mathrm{B}$ of section 2, it was found that the maximum surface temperature recorded for the outside layer of the panels was 61 degrees in model A. This fact and the comparison of temperatures from the model throughout the year confirms that the estimation of BIPV elements heating at averages of $40^{\circ} \mathrm{C}$ and $55^{\circ} \mathrm{C}$ during winter and summer was adequate. The temperature comparison for the different BIPV systems can be found on the appendix.

Having quantified the increase in cooling load for the building due to the utilization of BIPV systems and qualified the potential energy that could be produced by each system, a comparison was made to determine if the energy produced by the panels would be larger than the increase in the cooling load. This comparison is detailed in Table 7. No results were reported for the application of insulation on the glazing (window) elements, although the thermal properties of windows can be ameliorated by increasing the glass pane thickness or incorporating reflective coatings, amongst other solutions, which were not developed for this report.

\subsection{Section 3 - Cost Analysis}

The current electricity tariff in the UAE for commercial use is 38 fils per $\mathrm{kWh}$ plus a fuel surcharge of 6.5 fils per $\mathrm{kWh}$. If BIPV systems were to be installed on the base case building, substituting windows or external wall elements on the fourth floor, the payback periods for the BIPV systems evaluated would range from a minimum of 14 years to not having a payback period at all, as is the case of BIPV 2. A simple analysis of minimum payback periods can be seen on Table 6. These payback periods do not consider the added cost of the balance of system for photovoltaic installations, insulation elements, labor or any other necessary investments. Even when 
Table 6. Comparison of the increase in cooling load caused by the utilization of BIPV systems and the energy produced

\begin{tabular}{|l|l|l|c|c|}
\hline Increase in cooling load due to using BIPV & $\mathrm{kWh}$ & 12891.40 & 24248.40 & 12891.40 \\
\hline Increase in cooling load due to using BIPV and insulation & $\mathrm{kWh}$ & 10344.00 & $\begin{array}{c}\text { Not } \\
\text { Applicable }\end{array}$ & 10344.00 \\
\hline Energy Produced by the BIPV System & $\mathrm{kWh}$ & $27,017.61$ & $17,211.26$ & $37,033.98$ \\
\hline Surplus of energy if not using insulation & $\mathrm{kWh}$ & $14,126.21$ & $(7,037.14)$ & $24,142.58$ \\
\hline Surplus of energy if using insulation & $\mathrm{kWh}$ & $16,673.61$ & $\begin{array}{c}\text { Not } \\
\text { Applicable }\end{array}$ & $26,689.98$ \\
\hline
\end{tabular}

deducting the cost of the façade elements that the BIPV systems replace, the payback periods will be larger than those listed on Table 8.

$$
\underset{\text { (i.e. does not account for time value of money) }}{\text { Simple Payback Period }}=\mathrm{A} /(\mathrm{B}-\mathrm{C})
$$

Where:

$$
\begin{aligned}
\mathrm{A}= & \text { Cost of BIPV system (AED) } \\
\mathrm{B}= & \begin{array}{l}
\text { Monetary value of BIPV energy } \\
\text { produced in a year (AED } / \mathrm{yr})
\end{array} \\
\mathrm{C}= & \begin{array}{l}
\text { Monetary cost of additional annual } \\
\text { cooling demand due to BIPV (AED } / \mathrm{yr})
\end{array}
\end{aligned}
$$

\section{Discussion and Conclusions}

From this approximated method, it was found that temperature conditions in the UAE translate into a lower efficiency of a photovoltaic cell when compared to the STC efficiencies reported by manufacturers, and from the calculations it can be seen that these differences are in the range of 0.5 to $1.04 \%$. However, conducting a sensitivity analysis and considering the available areas of application of BIPV systems for this model, the slight differences in efficiency can cause large decreases in the energy production of a system. It is also very important to recognize that this study has not taken into account other external factors that influence the energy performance of photovoltaic systems, such as the impact of humidity, dust, pollution, rain, clouds, shading or fog; any losses in the system such as those derived from conversion, transmission and maintenance; or rated power output decrease due to degradation, which has been reported at a typical $0.5 \%$ per year [20]. The consideration of other factors would further decrease each system's energy production and would therefore make the installation of current BIPV systems an even less financially viable option.

As for the effect of integration of PV systems on a commercial building's cooling load, an approximated method to assess the performance of building integrated photovoltaics has been proposed and tested, and it was found that some systems result in a larger increase in cooling load than the amount of electricity that they produce. This could be avoided by installing the systems on locations where no cooling loads are necessary, such as roofs, plant rooms or parking areas. Other proposed systems would incorporate insulation or ventilated facades on the building envelope, which would increase the installation's cost. A simple insulation element was incorporated in the models; however, the findings did not show that this was a significant solution to the cooling load increase.

The loads that were considered for this study were the cooling loads, since they represent the majority of the energy consumption of commercial buildings. Other loads such as lighting and appliances should be considered in order to have a more thorough representation of a real building. The implementation of BIPV systems could provide additional shading or reduce the light transmission to the inside of the building, which could have an impact in the lighting load.

The building that was modeled was isolated from any other structures. In reality this is not an ideal scenario since it is expected that other buildings would be in proximity, having an impact on the shading and possibly reducing the available incident solar radiation, causing a reduction in the overall energy harvested from the BIPV system. Before the implementation of any BIPV system, all external factors should be modeled in order to find the optimum location for the system. 
Table 7. Simple Payback Periods for BIPV Systems

\begin{tabular}{|l|l|c|c|c|}
\hline $\begin{array}{l}\text { Cost per square meter of BIPV } \\
\text { system }\end{array}$ & Units & BIPV 1 & BIPV 2 & BIPV 3 \\
\hline $\begin{array}{l}\text { Maximum area of BIPV system } \\
\text { that can be installed on the } \\
\text { fourth floor }\end{array}$ & $\mathrm{Sqm}$ & 229.00 & 314.00 & 800.00 \\
\hline $\begin{array}{l}\text { Cost of the system in that area } \\
\text { (A) }\end{array}$ & $\mathrm{AED}$ & $89,055.56$ & $130,410.0$ & 229.00 \\
\hline $\begin{array}{l}\text { BIPV Energy Produced in a year } \\
\text { per square meter }\end{array}$ & $\mathrm{kWh} / \mathrm{sqm} \cdot \mathrm{yr}$ & 117.98 & 54.64 & $183,200.0$ \\
\hline BIPV Energy Produced in a year & $\mathrm{kWh} / \mathrm{yr}$ & $27,017.61$ & $17,211.26$ & $37,033.98$ \\
\hline $\begin{array}{l}\text { DEWA based value of BIPV } \\
\text { energy produced in a year (B) }\end{array}$ & $\mathrm{AED} / \mathrm{yr}$ & $12,022.84$ & $7,659.01$ & $16,480.12$ \\
\hline $\begin{array}{l}\text { Additional cooling energy } \\
\text { demand in a year }\end{array}$ & $\mathrm{kWh} / \mathrm{yr}$ & $12,891.40$ & $24,248.40$ & $12,891.40$ \\
\hline $\begin{array}{l}\text { DEWA based cost of additional } \\
\text { cooling demand in a year (C) }\end{array}$ & $\mathrm{AED} / \mathrm{yr}$ & $5,736.67$ & $10,790.54$ & $5,736.67$ \\
\hline Simple Payback Period & Years & $\mathbf{1 4 . 2}$ & Never & $\mathbf{1 7 . 1}$ \\
\hline
\end{tabular}

A factor that should be taken into consideration is the occupancy of the building and the behavior of its occupants. The model was created assuming that the air conditioning system would be continuously on and that the full building would have the constant occupancy ratio expected for an office building.

It is important to analyze the application of BIPV elements in real operation conditions to further corroborate the results from the models, following the requirements and regulations focused on the reduction of energy consumption from fossil fuels and the increase of energy from renewables.

The characterization of the above delineated elements in real operation conditions, minimizing uncertainties and for every particular project where BIPV systems are intended to be installed is necessary to create reliable models that could be the basis for decision making. It is recommended that product manufacturers and developers consider the modeling and modification of BIPV systems to have better thermal characteristics than the façade envelope elements that they replace, and that further research is conducted in order to modify BIPV systems to be more adequate for their application in hot weather conditions, profiting from the availability of high solar irradiance in these regions.

\section{Acknowledgements}

This dissertation was developed under the supervision of Dr. Kirk Shanks, who I thank for his guidance and motivation. It has been a pleasure working with him and the faculty members at Heriot Watt University.

I would like to thank the team at Ted Jacob Engineering Group Dubai for their incredible support during the course of this Master's Degree programme. Special thanks to Bob Mitchell, Qamar Nizami, Ted Jacob and Shad Shabbas, without whose support, advice and knowledge, this enriching experience would've not been possible.

I finally thank Simon Hough, my family and my friends, who have believed in me at every step of this journey and have offered their absolute support and encouragement.

\section{References}

[1] World Business Council for Sustainable Development, "WBCSD Pathways to 2050: Energy and Climate Change," Geneva, 2005.

[2] Marketline, "Global Energy Consumption September 2014," 2014.

[3] DEWA, "Electricity Statistics 2014," 2014. [Online]. [Accessed 20 August 2015].

[4] K. Shanks and E. Nezamifar, "Impacts of climate change on building cooling demands in the UAE," in Paper presented at SB13 Dubai: Advancing the Green Agenda Technology, Practices and Policies, Dubai, United Arab Emirates, Dubai, 2013.

[5] H. Radhi, "On the optimal selection of wall cladding 
system to reduce direct and indirect $\mathrm{CO} 2$ emissions," Energy, no. 35, pp. 1412-1424, 2010.

[6] Abu Dhabi Urban Planning Council, The Pearl Rating System for Estidama. Building Rating System, 1.0 ed., Abu Dhabi, 2010.

[7] M. Thomas, "The Future of PV Starts Now," $P V$ Magazine, 26 July 2012.

[8] A. Bouyamourn, "UAE to cut government spending for first time in 13 years," The National, 27 July 2015.

[9] J.-H. Yoon, S.-R. Shima, Y. S. An and K. H. Lee, "An experimental study on the annual surface temperature characteristics of amorphous silicon BIPV window," Energy and Buildings, vol. 62, pp. 166-175, 2013.

[10] B. P. Jelle, C. Breivik and H. D. Rokenes, "Building integrated photovoltaic products: A state-of-the-art review and future research opportunities," Solar Energy Materials \& Solar Cells, vol. 100, pp. 69-96, 2012.

[11] H. Radhi, "Energy analysis of façade-integrated photovoltaic systems applied to UAE commercial buildings," Solar Energy, vol. 84, no. 12, pp. 20092021, 2010.

[12] P. K. Ng, N. Mithraratne and H. W. Kua, "Energy analysis of semi-transparent BIPV in Singapore buildings," Energy and Buildings, vol. 66, pp. 274281,2013

[13] L. Olivieri, E. Caamano-Martin, F. Olivieri and J. Neila, "Integral energy performance characterization of semi-transparent photovoltaic elements for building integration under real operation conditions," Energy and Buildings, no. 68, pp. 280-291, 2014.

[14] A. B. S. Bahaj, P. A. James and M. F. Jentsh, "Potential of emerging glazing technologies for highly glazed buildings in hot arid climates," Energy and Buildings, no. 40, pp. 720-731, 2008.

[15] Dubai Municipality, Green Building Regulations \& Specifications, Dubai, 2015.

[16] J.-H. Yoon, S.-R. Shim, Y. S. An and K. H. Lee, "An experimental study on the annual surface temperature characteristics of amorphous silicon BIPV window," Energy and Buildings, no. 62, pp. 166-175, 2013.

[17] Climatebase, "The Archive of Climatic Data," 2012. [Online]. http://climatebase.ru/station/41194/?lang=en. [Accessed 15 August 2015].

[18] S. Armstrong and W. Hurley, "A thermal model for photovoltaic panels under varying atmospheric conditions," Applied Thermal Engineering, vol. 30, pp. 1488-1495, 2010.

[19] M. A. Maehlum, "The Real Lifespan of Solar Panels," 2014. [Online]. Available: http://energyinformative.org/lifespan-solar-panels/. [Accessed 5 August 2015].

[20] C. Peng, Y. Huang and Z. Wu, "Building-integrated photovoltaics (BIPV) in architectural design in China," Energy and Buildings, vol. 43, pp. 35923598, 2011.

[21] D. H. Li, T. N. Lam and K. Cheung, "Energy and cost studies of semi-transparent photovoltaic skylight," Energy Conversion and Management, vol. 50, no. 8, pp. 1981-1990, 2009.

[22] Guardian Industries Corp., "What is the difference between SHGC (Solar Heat Gain Coefficient) and SC (Shading Coefficient)?," 2015. [Online]. Available: https://www.guardian.com/commercial/ToolsandReso urces/Resources/FAQ/SHGC-versus-SC/index.htm. [Accessed 2 August 2015]. 